\title{
Religion in the public sphere and the well-being of the poor: A practical theological perspective
}

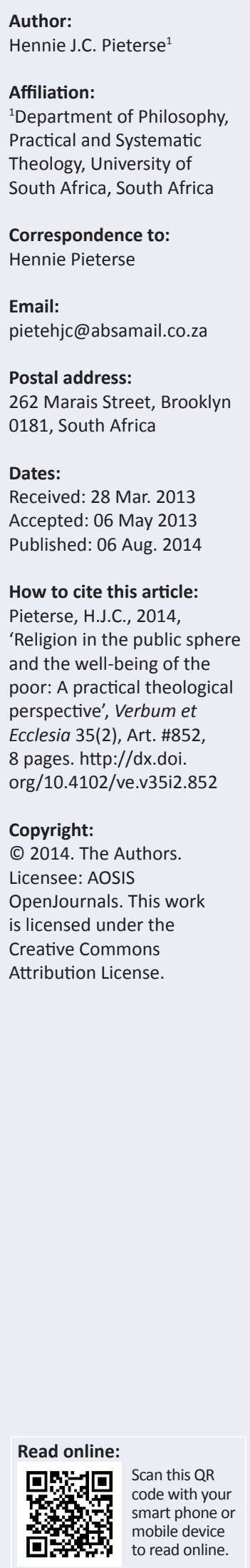

This article forms part of my research participation at the University of South Africa in the project Religion, health and well-being in Southern Africa: Practical theological perspectives. All the themes we are addressing in this project are public issues. Therefore the basic question in this project pertains to where and how religion, in this case Christian religion, is involved in public discourses and actions regarding problems in public life in South Africa. The specific research question in this article is: what effects do congregational projects by church members, directed to the poor, have on their experience of well-being? Congregational projects by church members directed to the poor are public actions by people with religious motivation addressing a public problem in South Africa. Therefore, these projects and their effects on the experience of well-being by the poor are religious actions in the public sphere. Firstly, I have conceptualised religion as well as the well-being of the poor in South Africa. The relationship between religion and wellbeing amongst the poor is then addressed. The conceptualisation has directed the formulation of half-structured interview questions in a qualitative empirical research in a sample from a population of pastors and their congregations who are practicing congregational projects directed at the poor in their vicinities. From the analysis of the contents of the interview, data categories have been formulated, which could then be phrased into a conceptual framework of the effects of these projects on the well-being of the poor. This research is an exercise in public practical theological research.

\section{Introduction}

This article forms part of my research participation at the University of South Africa in the project Religion, health and well-being in Southern Africa: Practical theological perspectives. All the themes we are addressing in this project are public issues. Therefore the basic question in this project pertains to where and how religion, in this case Christian religion, is involved in public discourses and actions regarding problems in public life in South Africa. The specific research question in this article is: 'What effects do congregational projects by church members, directed to the poor, have on their experience of well-being?' Congregational projects by church members directed to the poor are public actions by people with religious motivation addressing a public problem in South Africa. Therefore these projects and their effects on the experience of well-being by the poor are religious actions in the public sphere.

Julian Müller, a friend of mine for many years in whose honour this article is written, has a prominent profile as a practical theologian who regularly participates in discussions on religious views, especially with Afrikaans speaking church members, mainly in Beeld, an Afrikaans secular daily newspaper. He constantly tries to find new language in a changed society and worldview to phrase the Christian belief of Afrikaans speaking Reformed people. His newspaper articles propose a progressive view in the light of the tension between tradition and renewal in the beliefs of many church members. His articles have always stimulated lively discussions on the public platform of a secular newspaper. His work in this regard is a good example of popular religious discourse in the public sphere. Professor Wilhelm Jordaan, in his regular weekly column in Beeld, stimulated this kind of debate again by asking what the church is doing in engaging with the growing number of people who have doubts about their Christian faith. A lively debate followed for six weeks in which many pastors and church members in the Afrikaans churches participated, which was concluded by Jordaan (2012:17) in Beeld on 11 December 2012. This debate is another example of public debates on religion in South Africa. In popular culture the role of religion in the public media is important. As Ganzevoort (2011) states:

It is hard not to think of the media or, broader, the realm of popular culture when we want to assess the public significance of religion. It may not be the only sphere where religion plays a major role in contemporary societies, but certainly in this sphere religion emerges in a vibrant, eclectic, and often innovative way. (p. 95)

More far-reaching and critical is the example of religion in the public sphere by the prophetic statement in a letter to the president, Jacob Zuma, by the most prominent Christian church leaders 
in our country, of which an edited version was published in the Pretoria News (Makgoba et al. 2012). This letter is signed by Archbishop Thabo Makgoba of the Anglican Church, Bishop Joe Seoka of the South African Council of Churches, Reverend Moss Nthla of the Evangelical Alliance of South Africa and Reverend Edwin Arrison of Kairos South Africa. They represent many of the $80 \%$ Christians that the South African population consists of. The following quote from the letter speaks for itself:

First, we note there are restless voices in different sectors of our society yearning for change - not for superficial change of one self-serving political leader for another, or one political party for another, but for a different kind of leadership that can restore hope for the poor. They yearn for a country with life-affirming values ... We know that the dream of a just, non-racial and prospering democracy is temporarily in eclipse - throttled by the actions (or lack thereof) of a generation of leaders who seem largely to have lost their moral compass. (Makgoba et al. 2012:14)

In this contribution, I am going to address the theme of this article in an academic way by working with the following framework. Firstly, I will conceptualise religion from a practical theological perspective and then I will conceptualise the experience of well-being by the poor. I will then show the relation between religion and the understanding of well-being by the poor, and lastly demonstrate, by means of qualitative empirical research, how religious actions in the public sphere have effects on the enhancement of the wellbeing of the poor in our country.

\section{Limitations}

The research and, as a result the article, have certain limitations. The goal of the research was not to interview the poor as a group. I have interviewed the pastors of the congregations that have meaningful projects directed to the poor within the environment of the congregations. I have interviewed two Black pastors of poor congregations who are receiving help from the projects of other congregations. I have also interviewed the few managers of institutions who are giving care to poor people where the congregations are reaching out to them. These pastors and the managers of the two institutions have informed knowledge of the effects of their projects on the basic needs of the poor. I regard them as knowledgeable on the information I need. It was also not the purpose of this article to discuss the causes of poverty, such as the effect of the greater systems in our society on poverty.

\section{Religion in a practical theological perspective}

It is very difficult to define the complex notion 'religion'. The only approach that can help us to get a grip on it is to view it from a certain perspective. Firstly, I will say something about religion in general and then narrow it down to Christian religion. Then I will approach Christian religion from a practical theological perspective in the Protestant understanding thereof, and specifically from a Reformed perspective. I am departing from the perspective that spirituality is a general phenomenon amongst all people, which is a worldview, caused by border experiences such as illness, crises and death (cf. ed. Van der Lans 1984:8-9). Religion is a certain expression of spirituality.

People now and again ask themselves the existential question of what the meaning and purpose of life is. We are confronted with these questions in the contrast experiences of crisis, evil, illness, death and disasters (Schillebeeckx 1990:25-26; Van der Ven, Dreyer \& Pieterse 2004:258). Human beings then draw from the depth of their being. The phenomenon of religiosity is connected with these existential questions and experiences. Religion is usually expressed in a certain cultural and social setting. These expressions can differ from culture to culture (King 1987:285-286). However, religion, as the search for a comprehensive orientation, has an inner logic of its own that is more fundamental than the various social and cultural forms in which it is manifested (Krüger 1989:38). Kobus Krüger emphasises the essential logic of religion. This 'essence' of religion surpasses the institutionalised forms of a religion, such as dogmas, rituals, symbols and social structures, which can give a different identity to one religious expression from another (Krüger ibid:51). He (Krüger ibid) understands religion as:

[T] he most radical, most comprehensive orientation to the world of which people are capable. Religion is the deepest sounding, the widest expansion of consciousness. That is its inner logic. Religions (the plurality of historical manifestations of religion) invested their noblest thoughts, aspirations and feelings in their concepts of god. (p. 76)

In Christian Protestant religion, the concept of God has been formed by different aspects and perspectives. It varies in the tensions of the dialectic between the understanding of Christian religion as prohibition and accusation, retribution and consolation, and on the other hand, religion as freedom and hope (Ricoeur 1974:440-467). Christianity traditionally accepted the existence of one, eternal, personal, spiritual, triune being: Father, Son and Holy Spirit (cf. Krüger 1989:1). God in the Christian tradition is the God of Abraham, Isaac and Jacob and the God and Father of Jesus, the Christ (Van der Ven et al. 2004:355). He revealed himself to people, whose witnesses of their experiences with God we find in the Bible, and he continues to do so today by means of our experiences with him in the biblical texts, for instance in the worship services and through preaching. The believer can have a personal relationship of obedience and love with God. Of the different typologies of the concept of the Christian God today, the immanent transcendence understanding of God, is the understanding that I accept from a Christian practical theological perspective (eds. Stoker \& Van der Merwe 2012:31-61; cf. Van der Ven et al. ibid:355-371).

An example of the interpretation of God's immanence and transcendence is the thinking of Paul Tillich. He understands God as the depth of being (Schüssler 2012:32). He continues:

Tillich not only turns against one-sided emphasis of transcendence, but also against a one-sided emphasis on immanence: God cannot be identical to the world of beings, because this would forfeit the abysmal nature or the aspect of inexhaustibility of God. (p. 35) 
His insight that the religious dimension is to be identified with the dimension of depth is also expressed in his formula that religion is the substance of culture and culture is the form of religion. According to this view culture is founded in an ultimate concern (Schüssler 2012:37).

In a longitudinal research project with grade 11 learners in private and state schools in the Johannesburg and Pretoria area during 1995-2001, the respondents gave the immanenttranscendent understanding of God the highest score in the empirical study (Van der Ven et al. 2004:371).

There is an existential participation between God and human beings. The concept of participation is not only useful to convey the relationship between God and human beings, but also to convey the relationships between human beings. There is an analogy of the relationship between God and humans, and humans with each other (Van der Ven et al. 2004):

The analogy lies in the fact that, if one links the two relationships together, the horizontal relationship between people is clearly founded in the vertical relationship with God, who, following Schleiermacher, may be said to permeate the horizontal relationship and to be present in it. (p. 359)

This is not a purely transcendent, but an immanently transcendent God (Van der Ven et al. 2004):

This God is beyond human beings, their knowledge and love; yet he is also the God who makes himself knowable and lovable in the depths of human existence. (pp. 359-360)

God is experienced as a personal God. We can stand in a relationship with God that is analogous to that which we could have with another human person (McGrath 1994:209). In the communion between God and believers, there is an interaction between God and humans. Faith can be understood as an actual dialogue and communication with God (Immink 2005):

God is a speaking God who makes himself known in his promises and commandments, which is how he speaks to us. And we explicitly address God in our prayers and our songs of praise. (pp. 125-126)

I am working with the practical theological approach based on Heitink's model of a practical theological theory of action (Heitink 1999:148-170). ${ }^{1}$ In Heitink's approach, the researcher can focus on the individual believer, on church and faith, and on religion and society (Heitink ibid:274-309). In my research for this article, I studied the effects of religious actions of Reformed congregations on the well-being of the poor - therefore, in the field of church and society. Heitink's approach to practical theology is bedded in, and theoretically supported by, Reformed theology.

\section{Well-being in the basic needs of the poor}

The theological perspective of God's intention with people is their well-being. 'The meaning of the kingdom of God lies in the beatitude "blessed are you"' (Van der Ven et al. 2004:199). The meaning of history under God's rule is being happy, 1.For the continual actuality of action theory in practical theology, see Mager (2012). satisfied and laughing (Schillebeeckx 1974:142-143). God is the God of all creation who wants people to develop and liberate themselves in their history to achieve their greatest potential and well-being (Schillebeeckx 1993:332).

Well-being, or welfare, is a general term for the condition of an individual or group, especially their social, economic, psychological, spiritual and medical state (cf. Dasgupta 1993). I am working with the basic needs for well-being of the poor in South Africa. These basic needs are well described (cf. Maslow 1943; Max-Neef 1991:16; Dreyer 2008:13).

From the different aspects in the basic needs of people for the experience of well-being, I have filtered out the basic aspects of needs and satisfiers from the literature as they apply to the context of the poor in South Africa. These aspects as themes are the following:

- Social relations and the well-being of the poor.

- Spiritual experience and the well-being of the poor.

- Basic economic provision and the well-being of the poor.

- Basic health provision and the well-being of the poor.

- Dignity restored and the well-being of the poor.

- Psychological attitude and the well-being of the poor.

These themes are translated into half-structured questions in the interview schedule.

\section{The relation between religion and the understanding of well-being by the poor}

Religion, in a positive sense, has the potential to change the position of people in society for the better. As an institution, religion can be an agent of social change (Coetzee 1985:118; Van der Ven et al. 2004:319). When people reach out to the poor with help and assistance, they usually ascribe it in our society as coming from God. This fact was phrased again and again by the poor in our context in interviews during the past years.

Ms K expresses the experience of God's action in the assistance of caring people who guide them to surmount poverty: 'I want to thank the NGO's for their attempts. They are created by God' (Pieterse 2001:106). Ms J, a poor White widow in an old age home, has to travel by bus once a month to a state hospital to have her bad eyes treated, and each time she has to cross a busy street to reach the hospital: 'Do you know, every time the Lord sends me somebody who asks whether he or she can help me cross the street' (Pieterse 2001:110).

Ms E, an illiterate domestic worker, says: 'God has always helped me, throughout my life.' She considers help she received during the floods as 'a gift from God' (Pieterse 2001:108). Mr A, in an interview on assistance to poor people in 2000, phrased it as follows: 'Through my solidarity with them and the projects in cooperation with them, they begin to believe that God really loves them and is also with them' (Pieterse 2001:108). 


\section{Empirical research on the effects of congregational projects to the poor on their experience of well-being}

\section{Research design}

I used the following research design for this empirical research (cf. Mason 2002:24-47). The aim of empirical research in social science is to provide contextually valid descriptions and interpretations of human actions, which are based on an in-depth, insider's perspective of people in their world (Mouton 1988, quoted by Dreyer 2010:17). I worked with an interpretive perspective in qualitative research. 'This perspective has its roots in hermeneutics, the study of the theory and practice of interpretation' (Nieuwenhuis 2007a:58). My research was done by means of a half-structured interview schedule with a sample. Since half-structured interviews allow openness to probing and are conducted where the respondents live (in their contexts), interpretation by the researcher is needed (Nieuwenhuis 2007b:87).

\section{Sample and respondents}

The sample for this study was taken in respect of people, not events, which we can find in qualitative sampling. I therefore identified and contacted key persons for the interviews (cf. Mason 2002:135-139). The research was done in an ethically responsible way. The anonymity of the participants was guaranteed, they participated voluntarily and their dignity was taken into consideration in the research process (cf. Dreyer 2010:8-10). All the interviews were conducted where the respondents live and work.

The sample of respondents for interviewing consisted of:

- pastors of congregations with projects to institutions and communities to benefit the poor

- the managers of the institutions.

The population of pastors where congregational projects directed to the poor is practiced, and where I have done previous research in this regard, is 14. My sample involved four of these pastors. Also, two pastors who receive help and work in poor communities, as well as persons who work with the poor in institutions, were also interviewed. The total of 10 respondents were the following:

- Respondent A is the pastor of a Dutch Reformed (NG Kerk) congregation in Gauteng (East Rand): male, highly qualified, middle-aged.

- Respondent B is the CEO of an institution caring for destitute people in KwaZulu-Natal: male, pastor, middleaged.

- Respondent $\mathrm{C}$ is the manager of a children's home in Kwazulu-Natal: male, tertiary training, young.

- Respondent D is the manager of an old age home in Kwazulu-Natal: female, tertiary training, middle-aged.

- Respondent E is the pastor of a Dutch Reformed (NG Kerk) congregation in Kwazulu-Natal: male, highly qualified, middle-aged.
- Respondent F is the pastor of a Dutch Reformed (NG Kerk) congregation in Gauteng (Pretoria region): male, highly qualified, middle-aged.

- Respondent $\mathrm{G}$ is the manager of the projects directed to the poor in the congregation of respondent F: female, tertiary training, middle-aged.

- Respondent H is the pastor of a Dutch Reformed (NG Kerk) congregation in North-West: male, highly qualified, middle-aged.

- Respondent I is the pastor of a Uniting Reformed Church congregation, working in a squatter camp in the Eastern Cape (Uitenhage): male, tertiary training, young.

- Respondent J is the pastor of a Uniting Reformed Church congregation, working in a squatter camp in the Eastern Cape (Blue Water Bay): male, tertiary training, middle-aged.

The interviews took place in three phases. The first phase of interviews was with five respondents (respondents A, B, C, D and E). After analysing the first five interviews, I approached two more respondents (respondents F and G) in the second phase with a view to compare the significant experiences and views of the first five respondents with the next two respondents to look for experiences and views that have not yet emerged. In the last phase, I approached respondents $\mathrm{H}$, $\mathrm{I}$ and $\mathrm{J}$ to see if I could find significant new information, but I could not. I therefore regard the data I generated during the interviews as saturated.

\section{Questions}

The questions in the half-structured interview schedule, based on the conceptualisation of well-being in the experience of the poor and open for probing, were the following:

- Family is important for the poor. What is your experience of their relations with their family?

- How is their relationship with a church as a faith community, and what is their experience with the congregational projects of the church?

- What is their experience of well-being through food provision, and clothing?

- How would you phrase their experience of a safe home to dwell in?

- Do they have access to medical care and what is their experience thereof?

- Is their dignity restored through the provision by the churches?

- Do you observe hope for the future with them?

\section{Analysis of the data}

I prepared the data from the interview material for analysis. Using assistants to transcribe data can be problematic because decisions often have to be made, especially when content analysis is used. Qualitative researchers therefore recommend that researchers do their own transcribing and preparation of the data, whilst taking a more objective stance to the interview material (cf. Bogdan \& Biklen 1998:92). I analysed the interview material using content analysis that identifies and summarises the content of messages and views 
(Nieuwenhuis 2007c:101). I used a data analysis based on an interpretative philosophy aimed at examining meaningful and symbolic content of qualitative data (Nieuwenhuis 2007b:99). During the analysis of the interview data, I looked for significant understanding, feelings, experiences and views on the effects of the church's projects on the well-being of the poor (Nieuwenhuis 2007b:99). The goal of this exercise was to establish categories that emerge from the raw data. The significant content of the interview material has been arranged under category themes according to the concepts of well-being as experienced by the poor (cf. Nieuwenhuis 2007c:108-109).

\section{Categories that emerged from the analysis of the interview data}

I coded the raw data and used the codes for the significant content emerging from interview data (cf. Saldana 2009:1-31). The codes substantiate the formulation of the categories.

\section{Category 1: Social relations and the well-being of the poor}

Code 1 - Part of a family system: Interview with respondent A: 'In my experience with the poor, for them to be part of a family system where help can be found, is extremely important' (A, male, middle-aged).

\section{Interview with respondent $B$ :}

'For the inhabitants of this institution of 130 poor people it is the end of the road. Their families don't want them. The care inspired by the love of God provides a community, which comes in the place of a family.' (B, male, middle-aged)

Interview with respondent $C$ : Most of the 150 children between 3 and 18 years old in this Christian based children's home with seven houses, run by committed house mothers, are Black. All children, irrespective of sex, race or belief, are accepted. These are orphans or children taken away by the state from their dysfunctional families. The goal of the care is to send the children back to their families when the situation has improved. During school holidays, if there are still parents, the children should go home. 'The older children don't want to go. They say there are no privacy, toilet or bathroom, and mostly no food - everything they have in the children's home' ( $C$, male, young). The children experience their co-inhabitants and the devoted housemothers as their new 'family'.

Interview with respondent $D$ : The children of many of the elderly people in the old age home have already retired with a small pension. The family visits their parents and grandparents when they are in Durban, but it is only occasionally. The family generally takes a distant position from the elderly who need financial assistance.

Interviews with respondents $F$ and $G$ : After the solar panels for electric light in the shacks have been established on the roofs, the more than 3860 people living in the informal settlements in the vicinity of the congregation have benefitted in their family lives. The parents can now be with their children at night when they do their homework. 'There are now better involvement of the parents with their children which have enhanced their well-being' ( $\mathrm{F}$, male, middle-aged). 'The training of domestic workers in cooking, baking and dressmaking has developed in better family relations' ( $G$, female, middle-aged).

\section{Category 2: Spiritual experience and the well-being of the poor}

Code 2 - Membership or connection with a church: Interview with respondent $A$ : 'The church is a place where they can go for help and see the help as coming from God' (A, male, middle-aged).

\section{Interview with respondent $B$ :}

'In their heart of hearts they want to be with their family. Their families don't want them. Here in the community of faith they experience well-being of a new "family".' (B, male, middle-aged)

Interview with respondent $C$ : All the children go to a church where they are at home. 'Religion and church going are very important for them. The home and care we provide are seen as the love and grace of God coming to them through our care' (C, male, young).

Interview with respondent $D$ : Two pastors alternatively conduct worship services on Sundays and Bible study occasions on Wednesdays in the old age home. 'Religion is very important for their feeling of well-being' (D, female, middle-aged).

Interviews with respondents $F$ and G: Through the projects to the disadvantaged communities in the squatter communities, the trust in the church of respondent $\mathrm{F}$ has grown. 'The projects have a positive effect on their view of the church' (G, female, middle-aged). 'The conflicts during food provision of different groups, and conflicts between the soccer players (on their request) have been constantly resolved by the manager of the congregation's projects' (F, male, middle-aged).

\section{Category 3: Basic economic provision and the well-being of the poor}

Code 3a - Food provision²: Interview with respondent A: Congregations provide good food to high school learners three times a week. It helps them to concentrate when studying.

Interview with respondent $B$ : The 130 inhabitants receive three meals a day, prepared by themselves in the institution's kitchen. 'They see the love of God in action when they receive food everyday' (B, male, middle-aged).

Interview with respondent $C$ : 'The children are very positive about the good food they have daily' (C, male, young).

Interview with respondent $D$ : Seven of the inhabitants only get an old age state pension and cannot pay for their lodging. The churches pay for these seven people for a good lunch every day. They are very grateful for God's care they experience practically in their lives.

2.Food provision has a profound impact on the well-being of poor learners. In a research project on this issue, the finding was that 'on average, children who received schoo meals consistently outperformed those who did not, by at least $10-15 \%$ in each of the three subjects' (Jansen 2007:17). 
Interviews with respondents $F$ and $G$ : During the canoe rowing practices on the nearby dam after school, the cook (provided by the congregation) prepares meals for the participating children before they start rowing. There are 30 children from disadvantaged communities participating at the moment.

Interview with respondent $H$ : The members of the congregation provide food to poor learners at various schools in the area of their church. 'They are not ashamed to go to the visiting church members at the school for their food' $(\mathrm{H}$, male, middle-aged).

Interview with respondent I: The congregation provides food for the job seekers who have to walk the whole day and then rush to the church in the evening for food.

Interview with respondent J: The congregation provides food for those who have nothing. Their reaction is: 'God has provided through the people who are helping' (J, male, middle-aged).

Code $3 \mathbf{b}$ - The provision of clothes: Interview with respondent $B$ : The poor inhabitants receive clothes given by the congregations when they need it and they feel good on these occasions.

Interview with respondent $D$ : The churches give clothes for the old age home and those who need it receive it from the manager discreetly.

Interviews with respondents $F$ and $G$ : Basic needs of families are addressed by providing them with blankets and clothes. 'They have to pay a minimal fee for the clothes' ( $G$, female, middle-aged). 'By paying something for the clothes, their dignity is recognised' (F, male, middle-aged).

\section{Code 3c - A safe home: Interview with respondent B:}

'A poor family (father, mother and child) stayed in the bush. We put them in an old caravan in our institution. The father died. The mother did not want to leave. She and her child feel[s] safe and very grateful to have a safe home.' (B, male, middle-aged)

Interview with respondent $D$ : The home has secure fencing and a guard at the gate. The frail elderly feel safe in this old age home.

Interviews with respondents $F$ and $G$ : In conjunction with Lloyds Register, solar panels were put on the roofs of the shacks where more than 3860 people live. Now they have free electric light and they can charge their cell phones. Before the congregation did this, the little homes were dark during the day and at night. People, especially high school children, were walking all over the place at night. Now they stay at home with their parents and they can do their homework:

'They now have safe homes and the children are going to school again. Their results at school are better. The well-being of the whole family has been enhanced. By having a facility to charge their cell phones, the parents can communicate with a wider world. They say that God is good for them.' (F, male, middle-aged)

The congregation has a team who check the sun panels and bulbs on a regular basis.

\section{Category 4: Basic health provision and the well-being of the poor}

Code 4 - Health provision: Interview with respondent $B$ : The inhabitants of this institution have free access to a government clinic for medicine in the vicinity. If they need to, they go to a provincial hospital nearby:

'One of our people who had a stroke somewhere, and then taken in by us, can now speak and walk. He cries everyday to express his gratefulness when I speak to him.' (B, male, middle-aged)

Interview with respondent $C$ : In the children's home, there is a sick berth with 10 beds and trained medical staff.

Interview with respondent $D$ : There is a good medical facility with six registered nurses for the elderly. Two visiting doctors are available: one for state patients and one for private patients. When needed, a state psychiatrist visits the home. Medicines are fetched and delivered from two chemists.

Interviews with respondents $F$ and $G$ : There are two state clinics nearby. The congregation runs a wellness centre where all people, including disadvantaged people, can receive professional therapeutic services. These services concentrate on difficulties regarding themselves, their life partners, family members, children, and God, or children struggling with educational problems.

\section{Category 5: Dignity restored and the well-being of the poor}

Code 5 - Dignity restored: Interview with respondent A: 'Food is given discreetly to the learners so that the others don't see it. In this way their dignity is safeguarded' (A, male, middle-aged).

Interview with respondent $C$ : With the care the children experience in the children's home, their dignity is restored.

Interview with respondent $D$ : 'The care we are giving to the elderly are intended to safeguard their dignity' (D, female, middle-aged).

Interview with respondent E: 'Many of those who receive help take the opportunity to better their lives and restore their dignity' $^{\prime} \mathrm{E}$, male, middle-aged).

Interviews with respondents $F$ and $G$ : The outreach of different well-managed projects to the disadvantaged communities in informal settlements in the vicinity of the congregation, have changed the situation of these people for the better. "The effects of these projects have helped to restore the dignity of our neighbours in our life world' (F, male, middle-aged).

\section{Category 6: Psychological attitude and the well-being of the poor}

Code 6 - Hope for the future: Interview with respondent $B$ : 'When they see God's works of love in our caring for them, it gives them hope for the future' (B, male, middle-aged).

Interview with respondent C: The children of the children's home perform well at school and some are studying at a 
university. In the recent past, the children were elected in leadership roles at the primary and high schools. They have a new and hopeful future.

Interviews with respondents $F$ and $G$ : The congregation has a child development centre. In conjunction with the Academy for Canoe Development, children from disadvantaged communities form part of the afterschool project. Life and handcraft skills are presented. This includes good manners, self-discipline and help with Mathematics, English and the use of a computer. The children also receive a meal before they start rowing. During holidays, fun and educational programs are presented, in conjunction with other resources, to children from informal settlements whilst their parents are at work. 'These children enjoy development of their academic skills, bodily development and civil manners, which give them hope for the future' (F, male, middle-aged). 'One of our children participated in the Africa Games in Tunisia' (G, female, middle-aged). The congregation also has a training centre where business skills training and mentoring to young black entrepreneurs takes place, as well as leadership training to disadvantaged communities. Sewing skills training, as well as a home management course, are also presented at the church. 'These training activities and help have opened up a new future for these people' ( $G$, female, middle-aged).

\section{Interpretation of the data}

The interpretation of the analysed data has a relation with the research question (Mason 2002:183-187). The research question that directed the research in this article is: 'What effects do congregational projects by church members, directed to the poor, have on their experience of well-being?'

The different aspects of the basic needs of the poor became categories in the analysis of the interview data. The basic experiences of well-being of the poor contained in the interview data, through the effects of the congregational projects, now fill the categories with conceptual content.

The category of spiritual well-being of the poor now forms the central concept in this conceptual framework of the effects of congregational projects on the well-being of the poor. All the other categories are related to this central concept. I formulated the central concept from the interview data as: God's love in action in the experience of well-being of the poor.

The other concepts, all in relation to the central concept, are:

- Social relations: The experience of God's love in being part of a family system as the well-being of the poor through the care of institutions supported by congregational projects.

- Basic economic provision: The experience of God's love in the provision of food, clothes and safe accommodation as well-being of the poor through the care of congregational projects.

- Basic health provision: The experience of God's love in nearby medical provision as the well-being of the poor through the care of congregational projects.
- Dignity restored: The experience of God's love when dignity is restored as the well-being of the poor through the care of congregational projects.

- Psychological attitude: The experience of God's love in hope for the future as the well-being of the poor effected by the support of congregational projects.

\section{Conclusion}

As an institution, religion can be an agent of social change (Coetzee 1985:118; cf. eds. Mendieta \& Van Antwerpen 2011). Congregational projects, as the effort of addressing the public issue of poverty in South Africa, are religious actions in the public sphere. Studying this problem in the field of congregational projects and their effects on the well-being of the poor, and offering the results for public discourse on the problem of poverty, is an exercise in public practical theology.

The results from this research are limited contributions to the wider discourse in theology and the social sciences. I have connected critically in previous articles with the research on poverty by Burger, Louw and Van der Walt (2010:62-73; cf. De Wet \& Pieterse 2012; cf. Wepener \& Cilliers 2010: 417-430; cf. Pieterse 2012). This research, however limited, may contribute to the public discourse on poverty of which Ignatius Swart (eds. Swart et al. 2010) has stimulated, and in my case with this article, the improvement of the basic needs of the poor, especially by the work the church is doing in this regard. Further research on the poor and the question of dependence on help from the church should be undertaken.

\section{Acknowledgements Competing interests}

The author declares that he has no financial or personal relationship(s) that may have inappropriately influenced him in writing this article.

\section{References}

Bogdan, R.C. \& Biklen, S.K., 1998, Qualitative research for education: An introduction to theory and methods, 3rd edn., Allyn \& Bacon, Boston.

Burger, R., Louw, M. \& Van der Walt, C., 2010, 'The challenge of poverty and social exclusion in post-apartheid South Africa', in I. Swart, H. Rocher, S. Green \& J. Erasmus (eds.), Religion and social development in post-apartheid South Africa, pp. 62-73, Sun Press, Stellenbosch.

Coetzee, J.K., 1985, 'Religion and social change', in G.C. Oosthuizen, J.W. Coetzee, J.W de Gruchy, J.H. Hofmeyer \& B.C. Lategan (eds.), Religion, intergroup relations and social change in South Africa, pp. 117-151, Human Sciences Research Council, Pretoria.

Dasgupta, P., 1993, An inquiry into well-being and destitution, viewed 15 February 2013, from http://www.oup.com/uk/catalogue/?ci=970198288350

De Wet, F.W. \& Pieterse, H.J.C., 2012, 'Die belang van die verrekening van metateoretiese vertrekpuntevir prediking en wetenskaplike navorsing in Homiletiek', In die Skriflig/ In Luce Verbi 46(2), 106. http://dx.doi.org/10.4102/ids.v4612.106

Dreyer, J.S., 2008, 'Practical theology and human well-being: An exploration of a multidimensional model of human action as conceptual framework', Practical Theology in South Africa 23(3), 3-22.

Dreyer, J.S., 2010, The research challenge: Doing empirical research in theology. Only Study Guide for CGM3704, University of South Africa, Pretoria.

Ganzevoort, R.R., 2011, 'Framing the gods: The public significance of religion from a cultural point of view', in L.J. Frances \& H-G. Ziebertz (eds.), The public significance of religion, pp. 95-119, Brill, Leiden/Boston.

Heitink, G., 1999, Practical Theology. History-theory-action-domains, William B. Eerdmans, Grand Rapids/Cambridge.

Immink, F.G., 2005, Faith. A practical theological reconstruction, William B. Eerdmans, Grand Rapids/Cambridge.

Jansen, J.D., 2007, 'The language of research', in K. Maree (ed.), First steps in research, pp. 14-22, Van Schaik Publishers, Pretoria. 
Jordaan, W., 2012, 'Ja vir die tradisie kan ook ja wees vir die nuwe', Beeld, 11 December, p. 17.

King, W.L., 1987, 'Religion', in M. Eliade (ed.), The encyclopedia of religion, vol.12, pp. 282-293, Macmillan Publishing Company, New York/London.

Krüger, J.S., 1989, Metatheism: Early Buddhism and traditional Christian theism, University of South Africa, Pretoria.

Mager,R., 2012, 'Action theories', in B.J. Miller-McLemore (ed.), The Wiley-Blackwell companion to practical theology, pp. 255-265, Wiley-Blackwell, Oxford.

Makgoba, T., Seoka, J., Nthla, M. \& Arrison, E., 2012, 'We must reclaim a future of hope, compassion', Pretoria News, 13 December, p. 14.

Maslow, A.H., 1943, 'A theory of human motivation', PsychologicalReview 50(4), 370-396. http://dx.doi.org/10.1037/h0054346

Mason, J., 2002, Qualitative researching, Sage, London.

Max-Neef, M., 1991, Human-scale development: Conception, application and further reflection, The Apex Press, New York.

McGrath, A.E., 1994, Christian Theology: An introduction, Blackwell, Oxford.

Mendieta, E. \& VanAntwerpen, J. (eds.), 2011, The power of religion in the public sphere, Columbia University Press, New York.

Mouton, J., 1988, Inleiding tot kwalitatiewe metodes [Introduction to qualitative methods], Raad vir Geesteswetenskaplike Navorsing, Pretoria.

Nieuwenhuis, J., 2007a, 'Introducing qualitative research', in K. Maree (ed.), First steps in research, pp. 46-68, Van Schaik Publishers, Pretoria.

Nieuwenhuis, J., 2007b, 'Qualitative research designs and data gathering techniques', in K. Maree (ed.), First steps in research, pp. 69-99, Van Schaik Publishers, Pretoria.

Nieuwenhuis, J., 2007c, 'Analysing qualitative data', in K. Maree (ed.), First steps in research, pp. 100-122, Van Schaik Publishers, Pretoria.

Pieterse, H.J.C., 2001, Preaching in a context of poverty, University of South Africa Press, Pretoria.
Pieterse, H.J.C., 2012, 'A grounded theory approach to the analysis of sermons on poverty: Congregational projects as social capital', Verbum et Ecclesia 33(1), 689. http://dx.doi.org/10.4102/ve.v33i1.689

Ricoeur, P., 1974, The conflict of interpretations: Essays in hermeneutics, Northwestern University Press, Evanston.

Saldana, J., 2009, The coding manual for qualitative researchers, Sage, Los Angeles.

Schillebeeckx, E., 1974, Jesus, het verhaal van een levende [Jesus, the story of a living person], Nelissen, Bloemendaal.

Schillebeeckx, E., 1990, Mensen als verhaal van God [People as narrative of God], Nelissen, Baarn.

Schillebeeckx, E., 1993, Plezier en woede beleven aan God's schlepping [Experiencing pleasure and anger in God's creation], Tijdschrift voor Theologie 33, 325-347.

Schüssler, W., 2012, 'God as "depth of being": On the relationship between immanence and transcendence in the thinking of Paul Tillich', in W. Stoker \& W.L. van der Merwe (eds.), Culture and transcendence. A typology of transcendence, pp. 31-44, Peeters, Leuven.

Stoker, W. \& Van der Merwe, W. (eds.), 2012, Culture and transcendence. A typology of transcendence, Peeters, Leuven.

Swart, I., Rocher, H., Green, S. \& Erasmus, J. (eds.), 2010, Religion and social development in post-apartheid South Africa, Sun Press, Stellenbosch.

Van der Lans, J. (ed.), 1984, Spiritualiteit. Sociaalwetenschappelijke en theologische beschouwingen [Spirituality: Social-scientific and theological perspectives], Ambo, Baarn. PMid:6439045

Van der Ven, J.A., Dreyer, J.S. \& Pieterse, H.J.C., 2004, Is there a God of human rights? The complex relationship between human rights and religion: A South African case, Brill, Leiden/Boston.

Wepener, C. \& Cilliers, J., 2010, 'Ritual and the generation of social capital in contexts of poverty', in I. Swart, H. Rocher, S. Green \& J. Erasmus (eds.), Religion and socia development in post-apartheid South Africa, pp. 417-430, Sun Press, Stellenbosch. 